悪性胆道閉塞に対する expandable metallic stent の使用経験と 再閉塞予防対策

\begin{tabular}{lllllll}
\multicolumn{10}{c}{ 青森県立中央病院外科 } \\
安 & 藤 & 秀 & 明 & 井 上 茂 章 神 雅 彦 \\
北 & 島 & 修 & 哉 & 菊 & 池 樹 夫
\end{tabular}

1994年10月から1995年10月の 1 年間に切除不能悪性胆道閉塞症例 5 例に対して expandable metallic stent (EMS) による胆管拡張, 維持術を施行した. 施行途中合併 症は認められなかった。すへてての症例で EMSによる胆道閉塞の解除が可能であった。 た, 左右肝管閉塞症例に対しては double stent として再開通させ, 再閉塞症例には EMS の再挿入 (stent in stent) 施行し再開通させた. EMSによる平均胆道開存期間は 4 力月 と従来行われてきた内痖化チューブによるものより短期間であり,さらなる工夫が必要 と考えられた.これに対して当科では，マイクロ波照射後のEMS 挿入を試みており，再 開通および開存期間延長に有用であった。

索引用語：悪性胆道閉塞, expandable metallic stent (EMS)，マイクロ波照射

\section{緒言}

根治手術不能症例における悪性胆道閉塞は，閉塞の 解除が生命予後およびQuality of life を左右する重要 な課題である。これらの症例に対し経皮経肝的あるい は内視鏡的に種々の胆道内瘦術が施行されてい $ろ^{1)-4\rangle}$. 近年では金属ステント (metallic stent) が考 案され5，その治療成績が報告されている. 今回われわ れは, 切除不能悪性胆道閉塞症例に対し, expandable metallic stent (EMS) による胆道拡張・維持を行いそ の使用経験を検討した．さらに，再閉塞症例に対する 対応および再閉塞予防のためにマイクロ波照射を行っ たので報告する。

\section{対象}

対象は，1993年10月から1994年10月の 1 年間に当科 で, 手術不能とした悪性胆道閉塞症例 5 例とした。 男 女比は $3: 2 て ゙$ 平均年齢は $52 \pm 12$ 歳であった。原疾患 は胆道癌 4 例, 胃癌肝門部リンパ節転移 1 例であった (Table 1).いずれの症例も閉塞性黄疸にて発症し, 経 皮経肝胆道造影 (PTC) では完全閉塞であった。

metallic stent は, 現在市販されているもののうち, self expandableのもの, すなわち, $Z$ stentおよび Wallstentを使用した。

1996年 6 月 10 日受付 1996年 8 月 30 日採用
Table 1 Expandable Metallic Stent 使用例

\begin{tabular}{lll}
\hline \multicolumn{1}{c}{ disease } & & \\
\hline bile duct cancer & $\mathrm{Br}+\mathrm{Bl}+\mathrm{Bs}$ & 1 \\
\cline { 2 - 3 } & $\mathrm{Bm}$ & 2 \\
\cline { 2 - 3 } & $\mathrm{Bi}+\mathrm{Ab}$ & 1 \\
\cline { 2 - 3 } hepatic hilar lymphnode metastasis & & 1 \\
\hline total & & 5 \\
\hline
\end{tabular}

\section{方 法}

EMS は, 閉塞性黄㾝症例に対し経皮経肝胆道ドレ ナージ (Percutaneous Transhepatic Biliary Drainage, 以下 PTBD) を施行し胆管内腔を確保し, ドレ ナージチューブにより内瘦化したのち EMS を留置. その後 1 週間外瘦チューブを留置し経過観察したのち 抜去退院とした.stent は, 総胆管狭窄に対しては 1 本, 肝門部胆管の場合は左右 2 本留置した。

また，再閉塞症例に対しては再度 PTBD を施行し， 内掼化したのち再度 Wallstent 置した.

さらに最近では，EMS 留置のみでは再閉塞が認め られるため, 開存期間延長を目的として EMS 留置前 に Microwave Tissue Coagurator (MTC) によるマ イクロ波照射を1.8，5，7mm๕ケーブル（Fig. 1)を 


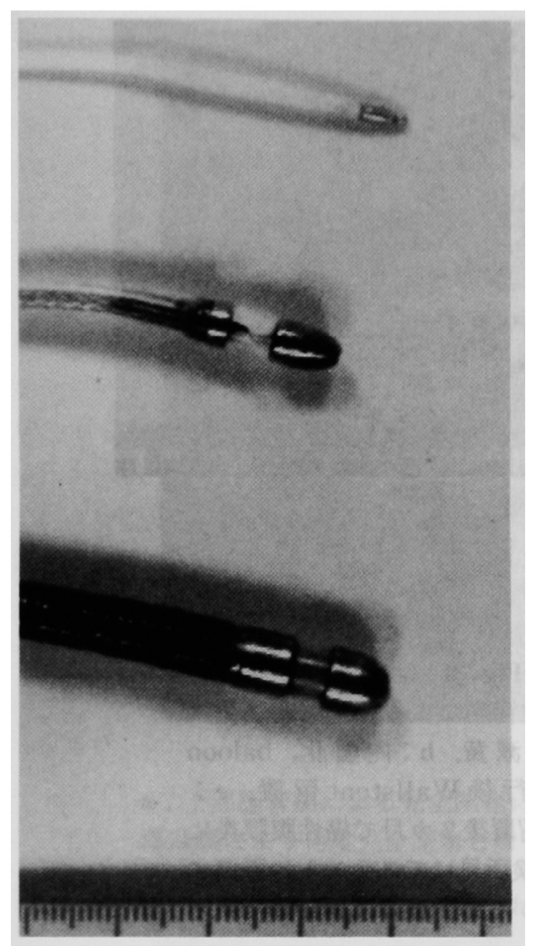

Fig. 1 マイクロ波照射用プロープ；上方より1.8,5， $7 \mathrm{~mm}$ ケープル

用いて45ワット，15秒間の計 3 回施行し十分な狭窄部 の掂張を行った後 ${ }^{6)-9)}$ (Fig. 2), EMS 留置した。 成 續

すべての症例につき，処置中に合併症を認めず， EMSの留置およびこれによる閉塞性黄疸の解除が可 能であった。

症例 1 ：肝門部胆管癌による閉塞性黄疸症例。肝門 部における完全閉塞（Fig. 3a）に対し7Fr PTCD チューブにて内瘦化した後, baloon dilation 後 Wallstent 留置 (Fig. 3b)．2 力月後癌性腹膜炎をきたし死 亡. 剖検所見ではステントは開存していた(Fig. 3c). 症例 3 ：下部胆管による閉塞性黄㾝症例. Zステン 卜を留置し黄疸解除するも，ステント上部からの腫瘍 伸展により再閉塞 (Fig. 4a)．再度 PTCS ルート確保 した後1.8mm〔ケーブルで MTC 施行し再度内瘦化. 5,7mm๘ケーブルにて追加照射した後 Wallstent を 再挿入 (Fig. 4b). 以後13力月間黄疸を認めない.

症例 4 ：肝門部胆管癌 $(\mathrm{Br}+\mathrm{B} 1+\mathrm{Bs})$ ．左右肝管に おける完全閉塞性黄疸に対し両側より PTCD 施行. 同 経路より $1.8 \mathrm{~mm}$ ケーブルで MTC 照射し癌部を凝
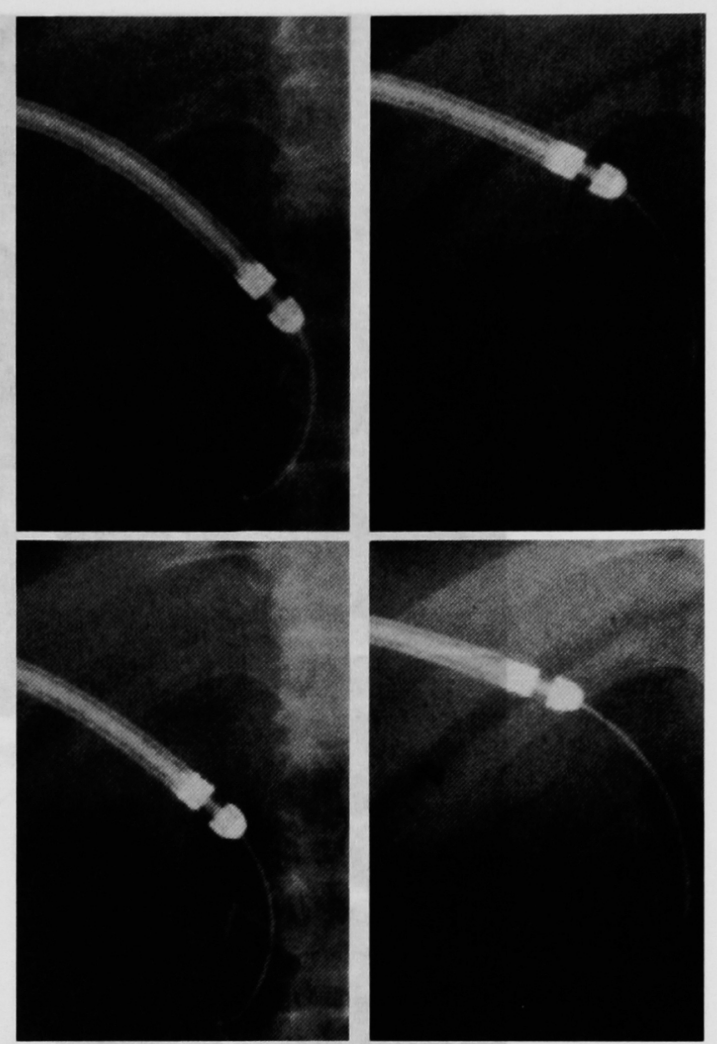

Fig. 2 マイクロ波照射法；㹡張させたPTCS ルー トよりガイドワイヤーを十二指腸まで誘䙳したの ち、これを通してマイクロ波照射用プローフ $(7 \mathrm{~mm}$

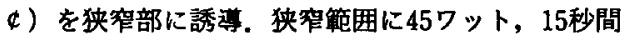
の条件で 3 回照射した。

固内瘦化, さらに $5,7 \mathrm{~mm}^{\circ} \mathrm{C}$ ケーブルで MTC 追加照射 の後左右肝管にWallstent 留置. 以後14力月黄疸を認 めない (Fig. 5).

症例 5 ：胃癌術後肝門部リンパ節転移による閉塞性 黄疸症例 (Fig. 6a). PTCD 後 Wallstent を留置した (Fig. 6b) が1 カ月でステント上部で再閉塞（Fig. 6c). 閉塞部を $1.8 \mathrm{~mm}$ ケーブルで MTC 照射し再内 瘦化し Wallstent を再挿入 (Fig. 6b). 以後黄疸を認 めなかったが，8力月目に癌性腹膜炎で死亡.

\section{考 察}

切除不能悪性胆道閉塞に対し, 経皮経肝的あるいは 内視鏡的内瘦術が開発治療されてきだー4). 内疸化維 持のためのチュープもポリエチレンチュープ214), metallic stent ${ }^{5)} し て$ 最近では expandable metallic stent が各種開発され使用報告されている(1)-5)10)-14). 

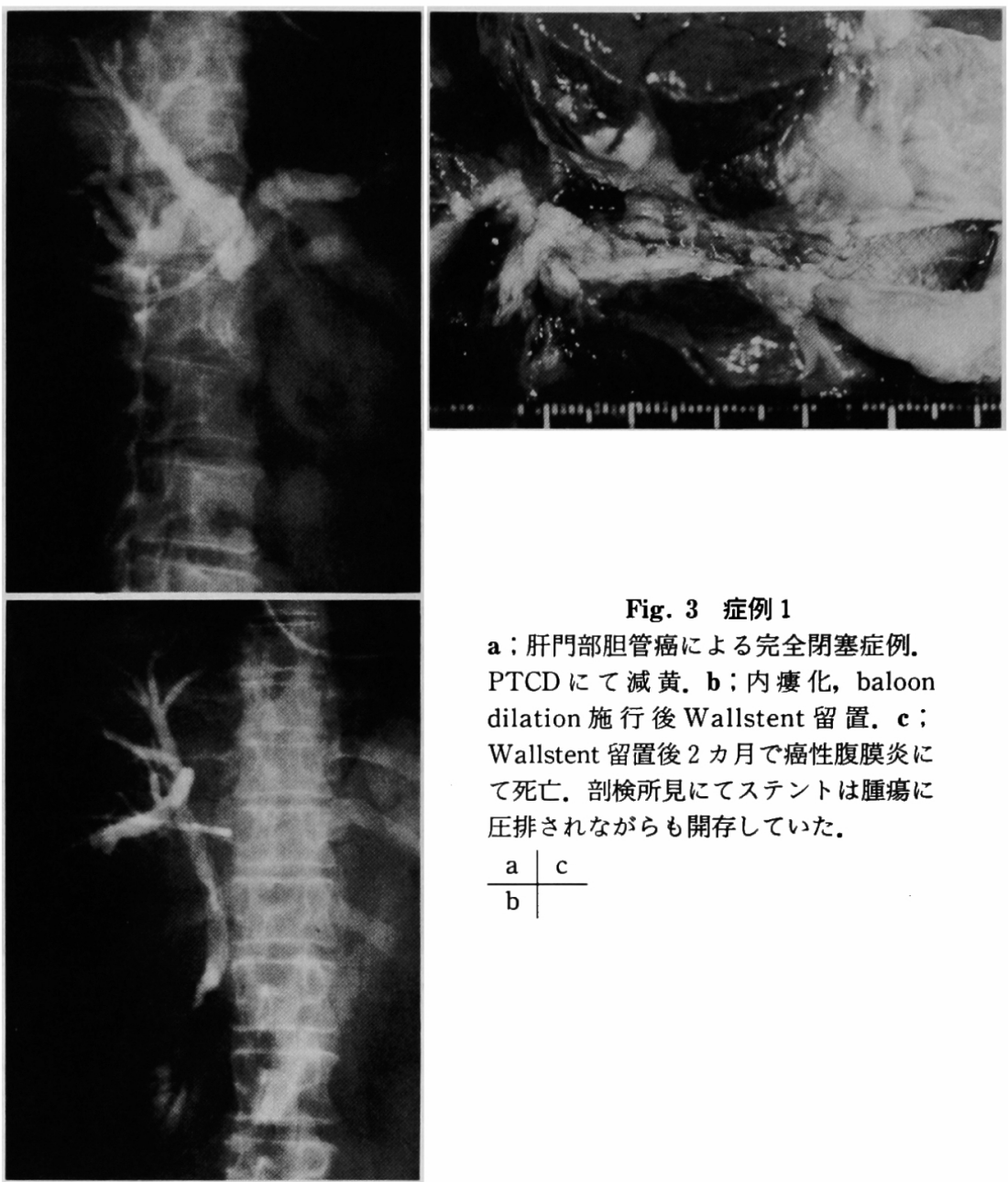

Fig. 3 症例 1

$\mathrm{a}$ ：肝門部胆管癌による完全閉塞症例. PTCDにて減黄. b : 内瘻化, baloon dilation 施行後Wallstent 留置. $\mathbf{c}$; Wallstent 留置後 2 力月で癌性腹膜炎に て死亡. 剖検所見にてステントは腫瘍に 圧排されながらも開存していた.

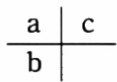

しかしながら, 切除不能悪性胆道閉塞症例が対象であ るため，低侵襲で短期間に治療終了できることが望ま れる.さらに, 十分な管径が維持され, 長期間閉塞し にくいことが当然要求される.

従来使用されてきた内瘦術は留置するチューブと同 径に胆道を拡張し, 再閉塞予防のためには $14 \mathrm{Fr}$ 以上の チューブを留置する必要があり，このため患者の苦痛 を伴い，その拡張術のため一定の期間を要していた。 この点において，EMSは7Frの introducerにより挿 入され，PTCD 経路のみでなく，ERCPによっても挿 入可能なため, 診断と同時に挿入することも可能であ る.さらに,その self expandable な特性により挿入後 も内腔拡張され, $20 \mathrm{Fr}$ 以上の内腔が確保される. 合併 症に関しては, 従来のポリエチレンチューブで報告さ
れていた膵管・胆囊管・肝内胆管の閉塞もほとんど認 められず. 手技の成功率および外瘦チュープの抜去率 も 9 割以上と良好な成績が報告されている ${ }^{1) 215)}$. ま た, ステントの開存期間は挿入後 1 年以上開存例も多 数報告あり ${ }^{13215)}$ ，ポリエチレンチューブと比較しても 遜色ない成績が報告されている。

しかし，その平均開存期間は $4 \sim 6$ 力月と結局ポリ エチレンチューブと同等の報告である. 症例で呈示の 如く，閉塞の原因はステント上または下部での腫瘍の 再増殖による閉塞あるいはステントの網目よりの腫瘍 伸展であった，再閉塞に対しては，自験例の如く再ス テントの挿入（stent in stent）にて対応可能であった. 従って, EMS 挿入時にその腫瘍の伸展範囲を検討し 十分な長さの EMS を挿入することが重要となる. 


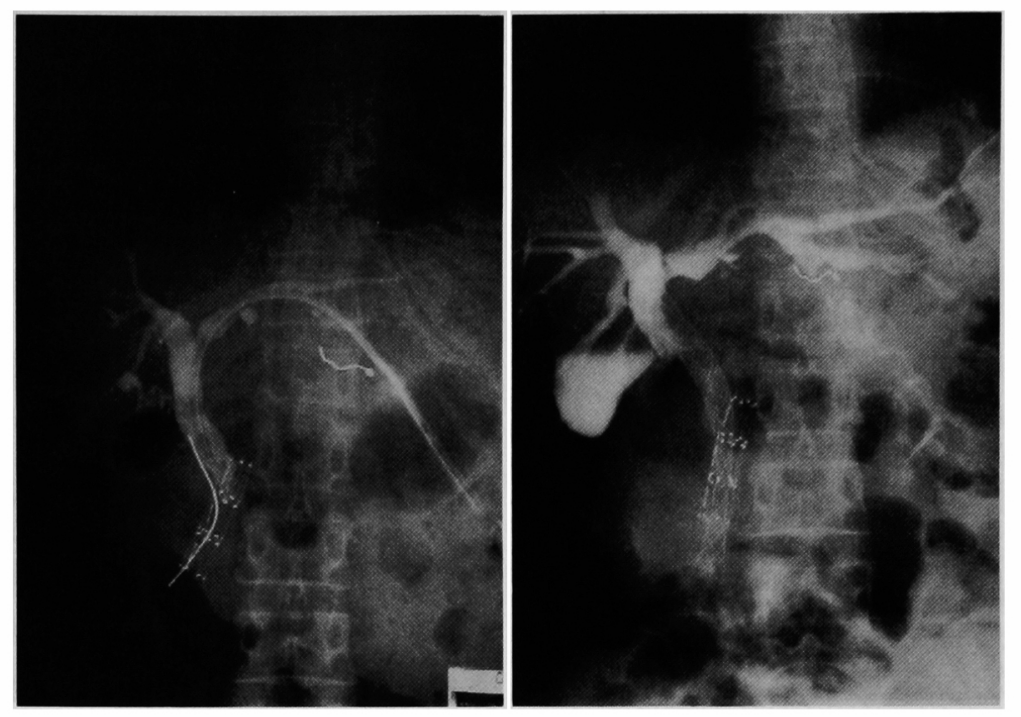

Fig. 4 症例 3

$\mathrm{a}$ ：下部胆管癌による完全閉塞に対し, $Z$ ステントを挿入したがステント上部よりの腫 瘍進展により再度完全閉塞となった. $\mathbf{b}$ ：マイクロ波照射により内瘦化したのち再度 Wallstent 留置.

a $\mid \mathrm{b}$

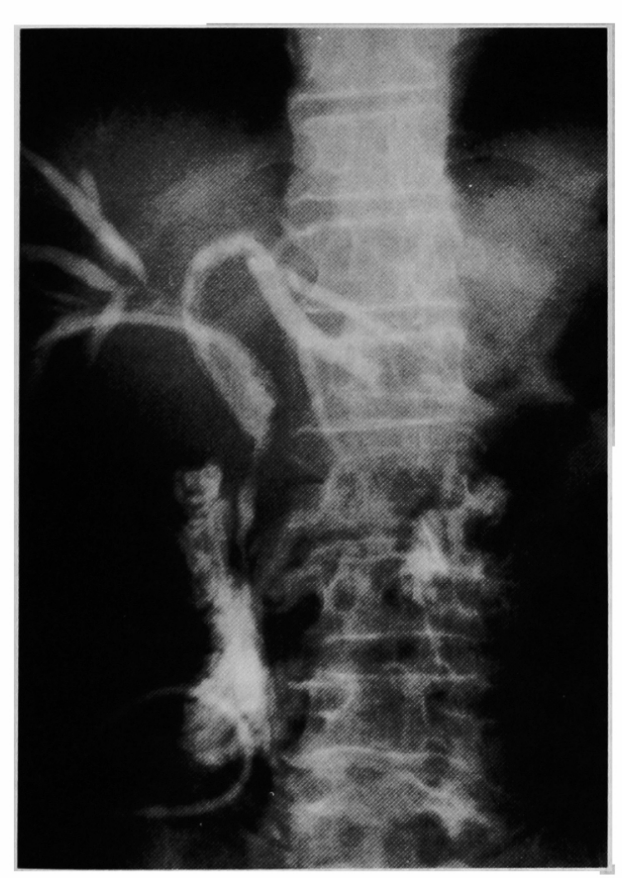

Fig. 5 症例 4

肝門部胆管癌による左右肝管完全閉塞例. マイクロ波 照射により内䨖化したのち左右肝管から Wallstent を留置.
悪性胆道閉塞のうち胆道癌症例では遠隔転移を示す ものは少なく, 胆道内腔を確保し無黄㾝状態を維持す ることにより生命予後のみならず qublity of life も良 好となる. 内瘦化の時点で生命予後が 4 〜 6 月であ れば従来の手段による EMS は非常に有効な手段であ るが, それ以上の生命予後が期待される場合, 胆管内 腔確保として EMS 挿入のみでは不十分となる.

このため, 当科では閉塞を内瘦化する際 MTC を施 行6) 9).これにより, 開存期間の延長が認められた。こ れはMTCよって胆管内腫瘍を凝固したことと同時 に, 凝固時に発生する熱が周囲へ温熱による抗腫瘍効 果をもたらしたものと推測された。すなわち，遠隔転 移および腹膜播種のない局所のみに腫場が限局してい る症例に関しては EMS 挿入前に MTC 照射しさらに 長期間の無黄疸期間を得ている.

\section{結 語}

1993年10月から 1994年10月の 1 年間に, 悪性胆道閉 塞 5 例に対し計 7 回の EMS による胆管拡張・維持術 を施行した。この際, EMS 挿入による合併症は認めら れなかった。

再閉塞の原因は，ステント近位端での腫瘍伸展・腫 瘍による圧迫・ステントの偏位であった。また，再閉 塞時には再ステント挿入による stent in stent が有効 

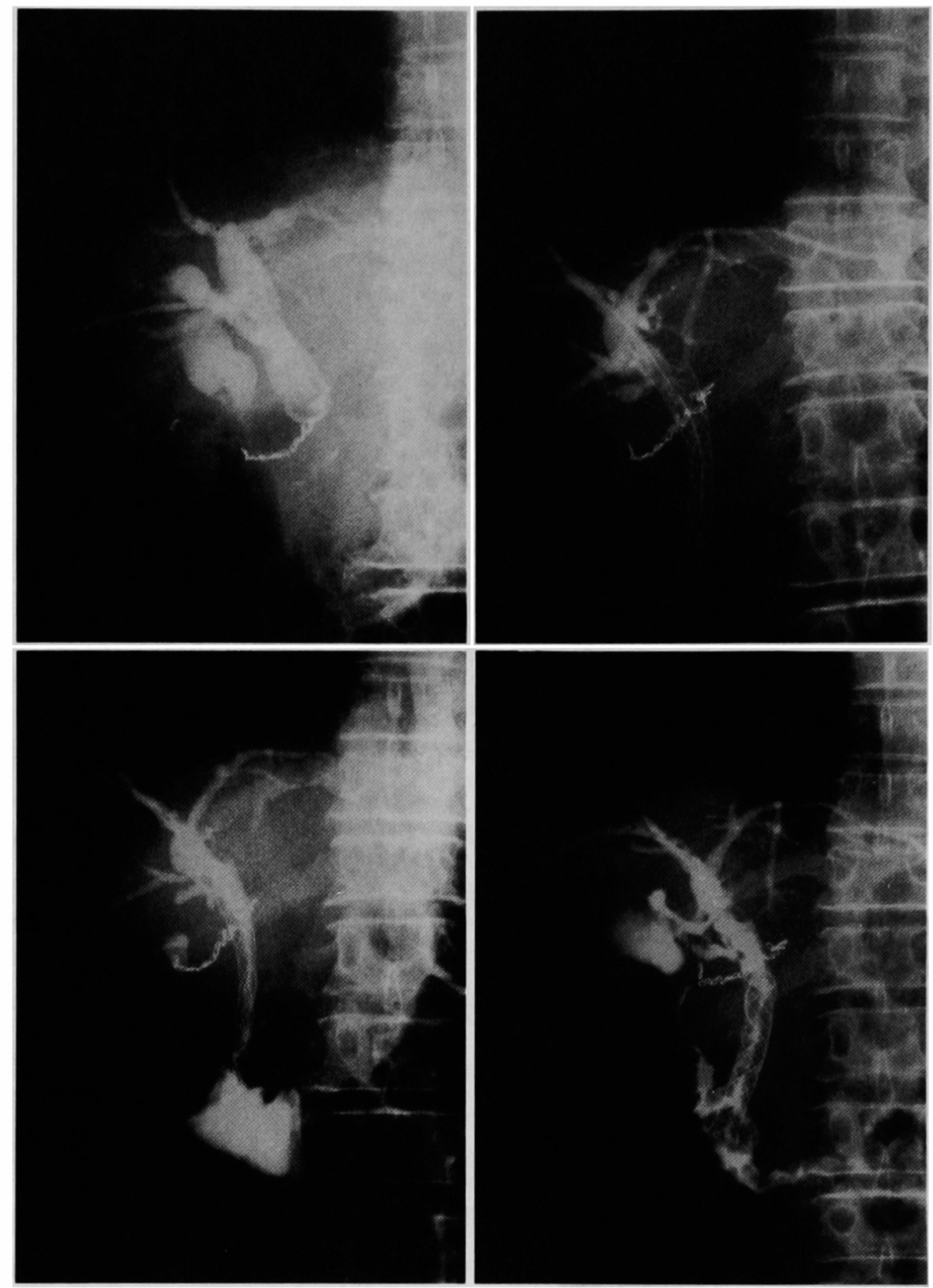

Fig. 6 症例 5

$\mathbf{a}$ ；胃癌術後肝門部リンパ節転移による閉塞性黄㾝. b ；内㾞化後 Wallstent 留置. $\mathbf{c}$ ： Wallstent 留置後 1 力月で再閉塞. $\mathbf{d}$ ；マイクロ波照射により内瘻化の後 Wallstent 再 留置 (stent in stent)

\begin{tabular}{l|l}
$\mathrm{a}$ & $\mathrm{c}$ \\
\hline $\mathrm{b}$ & $\mathrm{d}$
\end{tabular}

であった。

再閉塞予防として, 挿入前の十分な拡張と留置範囲 の検討が重要で, さらに, 挿入前 MTC 照射は有用で あった。

\section{文献}

1）小川 薫, 佐藤信紘：胆道狭窄に対する IVR, 特 に経皮経肝的アプローチによる胆道バルーン拡張
術および金属ステントを用いた胆道内瘻術につい て. 臨外 49: 955一-964, 1994

2) 西田博利, 吉岡哲也, 阪口 浩他: 胆道閉塞のステ ント治療. 病態生理 $13: 616$ - 625,1994

3) Lameris JS, Stoker J, Nijs HGT, et al : Malignant biliary obstruction: Percutaneous use of self-expandable stents. Radiology 179: 703- 
707, 1991

4) Lammer $J$, Neumayer K: Biliary drainage endoprostheses: Experience with 201 placements. Radiology $159: 625-629,1986$

5）友田 要, 白 鴻志, 堀 信一他：メタリックステ ントの開発。病態生理 $13: 589-594,1994$

6）井上茂章, 北島修哉, 今 明秀他：肝門部悪性胆道 狭窄に対するPTCS下マイクロ波凝固拡張およ び温熱療法。青森中病医誌 $36: 289-295,1991$

7) 中村広志：胆道悪性閉塞に対する経皮的マイクロ 波凝固療法の試み.日消病会誌 $84: 1141,1987$

8）関 寿人：経皮経肝胆道鏡下マイクロ波による悪 性胆道狭窄の治療. Gastroenterol Endosc 32 : $1646-1655,1990$

9）唐沢英偉：マイクロ波による胆管癌の経皮的温熱 療法の検討。胆と脺 8:183-191, 1987

10) Gillams A, Dick R, Dooley JS, et al: Selfexpandable stainless steel braided endoprostesis for biliary strictures. Radiology 174 : 137-
140,1990

11) Yoshioka T, Sakaguchi H, Yoshimura H, et al: Expandable metallic biliary endoprostheses: Preliminary clinical evaluation. Radiology 177 : $253-257,1990$

12) Adam A, Chetty N, Roddie M, et al: Selfexpandable stainless steel endoprostheses for treatment of malignant bile duct obstruction. AJR 156: 321-325, 1991

13) Irving JD, Adam A, Dick $R$, et al: Gianturco expandable metallic biliary stents : Result of a european clinical trial. Radiology 172:321326, 1989

14) Coons HG: Self-expandable stainless steel biliary stents. Radiology $170: 979-983,1989$

15）小川 毫：悪性胆道狭窄症例に対する金属ステン トを用いた経皮経肝胆道内瘦術の治療成䋶. 日臨 外医会誌 $55: 863-870,1994$

\title{
EXPANDABLE METALLIC STENT FOR MALIGNANT BILIARY OBSTRUCTION AND MANAGEMENT FOR RE-OBSTRUCTION
}

\author{
Hideaki ANDO, Shigeaki INOUE, Masahiko JIN, Shuya KITAJIM \\ and Yoshio KIKUCHI \\ Department of Surgery, Aomori Prefectual Central Hospital
}

From October 1994 to October 1995, five inoperable patients with malignant biliary obstruction were treated with a total of percutaneously inserted self-expandable metallic endoprostheses for palliative biliary drainage. Successful placement of expandable metallic stent (EMS) was achieved in all patients without complication. The biliary obstruction of bilateral hepatic ducts due to hepatic hilar bile duct cancer was treated with two EMSs through the bilateral percutaneous transhepatic routes. The verage period of external or internal catheter free without jaundice was four months, which was shorter than those with other conventional methods such as plastic stents. Main cause of reobstruction was tumor ingrowth or proximal overgrowth after EMS insertion. Therefore, patients with reobstruction after EMS placement were treated again with EMS (stent in stent).

According to these results, the patients treated with EMS require the additional treatments to prolong the effect of EMS internal drainage. We have managed such patients with the microwave tissue coagulation against the malignant biliary obstruction through the roue of percutaneous transhepatic biliary drainage in addition to EMS. The preliminary result shows the feasibility of microwave coagulation therapy to prolong the period of catheter free and jaundice free. 